\title{
Research on the Background of Talent Development in Local Applied Undergraduate Colleges
}

\author{
Lihua Huang \\ Fuzhou University of International Studies and Trade \\ Fuzhou, China 350200
}

\author{
Wei Zhao \\ Dhurakij Pundit University \\ Bangkok, Thailand
}

\begin{abstract}
Local applied undergraduate colleges need to thoroughly implement the spirit of the 19th session of national congress of the communist party of China. As an important part of China's higher education, local applied undergraduate colleges must grasp the new ideas and new missions that are focused on in the new era. For the research on the development of domestic applied undergraduate colleges and universities, the general development trend of higher education at home and abroad and the development status of domestic applied undergraduate colleges should be first recognized. Therefore, only by clarifying the background of the research object from the two dimensions of the domestic and international environment, can we analyze the significance of the development of local applied undergraduate colleges in the context of the new era.
\end{abstract}

Keywords-local applied; undergraduate colleges; talent development

\section{INTRODUCTION}

Upholding the leadership of the party is the bottom line that local applied universities must follow. The 19th session of national congress of the CPC clearly stated that building an educationally powerful country is the basic project for realizing the great rejuvenation of the Chinese nation. It is necessary to give priority to the education cause and realize the intension-type development of higher education. Applied undergraduate colleges should cultivate new high-quality applied talents in the new era and improve the quality of education and teaching. In terms of personnel training, some countries with more developed higher education are cultivating the two types of talents - "academic talents" and "applied talents" respectively, which is distinct and has a long history.

\section{FOREIGN BACKGROUND OF LOCAL APPLIED UNDERGRADUATE TALENT DEVELOPMENT}

There was the applied undergraduate education in foreign countries in early times, but it was then not called the applied undergraduate education. In developed countries, the applied undergraduate education is closely related to the popularity of higher education. As higher education has gradually been popularized, it is necessary to reform corresponding teaching content according to the type of talent training. Curriculum change is the inevitable way of popularization of higher education. Course changes first occurred in the disciplines of natural science. And then engineering courses began to change, followed by vocational courses. The pragmatic idea of university education is a great contribution of pragmatism philosophy to education. Constructing practical life experience in university education ideas is an important embodiment of pragmatic philosophical thinking. Its important ideology is that life knowledge has the practical value of making people happy. Life knowledge comes directly from life, and it is directly connected with the careers that students will be engaged in in the future. When the popularization of higher education developed to a certain stage, everyone has gradually accepted the concept of higher vocational education. At this time, higher education gradually developed into the professional and popular local applied education. At this time, the essential connotation of higher education development has also changed. Some countries have gradually introduced vocational certificate education into higher education, such as the United Kingdom and some Commonwealth countries. This trend of introducing professional certificate education into higher education should not be ignored. For example, the British government wanted to establish a system in which the government must provide talents with higher level of skill base to the society and increase the technology investment to promote economic growth. The UK has considered technology investment as an important factor in promoting economic growth. Germany's vocational education system is known worldwide for its "dual system". In the 1960s and 1970s, Germany's industry and economy developed rapidly. The major companies in the Federal Republic of Germany needed applied technical talents to join. Therefore, Germany established many applied science universities and vocational colleges. However, the unemployment rate in Germany has been increasing in recent years, and the employment rates of many traditional undergraduate colleges have been declining. Many colleges and universities have run the model of cooperating with enterprises and have introduced the "dual system", hoping to change the situation in which the employment rate has been declining through this model. There are three types of dual-system education models that have been initially formed in Germany: 1. Vocational colleges and economics and management colleges that focus on cultivating local applied talents; 2 . Applied science universities that focus on cultivating practical talents; 3 . Comprehensive universities. After more than 50 years of development, these three models have been mature and popular. At present, the applied science and technology universities have accounted for half of German higher education. 
Due to the industrialization process and the popularization of higher education in Germany, the applied science and technology universities were founded in the late 1960s and early 1970 s in Germany. After nearly 50 years of development, the applied science and technology universities in Germany now have relatively mature school-running concepts, talent training objectives, educational system and degree settings, admissions systems, speciality setup, teaching links, schoolenterprise cooperation, and faculties, and have established a relatively complete application-oriented senior talent training system. This talent training model system is very popular among the society because of its clear talent training purposes. The talent training model of the applied science and technology universities in Germany provides many references for the development orientation and teaching reform of many local undergraduate universities in China.

With the continuous development of the world economy and technology, exchanges between countries have been strengthened, and technical exchanges between countries have also been promoted. When carrying out the transformation of the educational model, colleges and universities should consider improving the school-running concepts and educational ideologies to meet the needs of the society.

On the whole, the education models of foreign applied undergraduate colleges mainly include the British "Sandwich" model, the US cooperative education model, and Japan's "Model of Combination of Industry, Official and University". The earliest model was the "Sandwich" model pioneered by the United Kingdom in 1903, in which students were required to conduct school studying and enterprise practice alternately to ensure their engineering practice abilities. In 1906, Americans localized this model and called it "cooperative education". However, in recent decades, applied undergraduate college education in countries such as Germany and Switzerland has been at the forefront of the world.

With regard to all of these models, first of all, researches conducted by the applied science universities and the basic universities include some continuous and similar activities. There are overlaps between the two kinds of researches and the researches cannot be simply viewed as two opposite kinds of studies. Many local applied researches are carried out on the premise of basic researches, and have been gradually covering more and more aspects of emerging sciences. In this sense, there is no clear dividing line between the researches of applied science universities and the researches of traditional universities. Of course, practical latitude and orientation are still the main guidelines for researches. Second, researches of applied science universities are considered to be the bridges between different fields of knowledge and practitioners in different fields of knowledge.

Making a comprehensive survey on the history and characteristics of foreign applied undergraduate college education, it seems that they are the results of the popularization of education. In fact, they are the inevitable results of economic and social development. In a deeper sense, they are the transfer of national talent strategy.

\section{THE DOMESTIC BACKGROUND OF LOCAL APPLIED UNDERGRADUATE TALENT DEVELOPMENT}

At present, the popular, diversified development of foreign higher education and the rapid development of domestic higher education have prompted the emergence of a large number of local applied undergraduate universities in China. More precisely, China's applied undergraduate colleges and universities are the products of economic and social development. With the promulgation and implementation of the National Medium- and Long-Term Education Reform and Development Plan (2010-2020), a new round of reform of China's higher education is imperative. Faced with the increasingly open international education environment and the fierce competition among domestic undergraduate universities, the survival and development of a large number of local applied undergraduate colleges has become the focus of the society.

In the 21 st century, higher education is inevitably the product of the popularization of higher education. We need to reflect on the original education model in which all universities were carrying out the traditional elite education. For countries with simultaneous economic and higher education development, they will adjust traditional undergraduate education in order to meet the talent demand of economic development and the market, thus developing local applied undergraduate education.

Many graduates are not employed because they have not well adapted to the changes in the talent demand of employers and the market. This kind of "structural unemployment" is caused by the problems of social development, employment system and college education. Although there are many factors that may cause the "structural unemployment", the problems of higher education are obvious. Faced with the shortage of "application-oriented" talents, the education authorities have proposed that applied talents should be cultivated by applied universities, and universities should strengthen the training of applied talents in all industries. Some undergraduate colleges have offered to position their talent training as the training of "applied" or "skilled" talents, and have advocated the transformation of the talent training objective from "academic undergraduate education" to "applied undergraduate education". Local applied undergraduate education is mainly undertaken by local applied undergraduate colleges. In China, newly established undergraduate colleges often position themselves as applied universities.

In China, newly-established undergraduate colleges generally position themselves as "applied undergraduate colleges". At the same time as the enrollment expansion of undergraduate colleges, the number of ordinary higher education institutions is also increasing rapidly. Many of the increased undergraduate colleges are coming from the upgrading of junior colleges. After upgrading, colleges and universities are faced with the choice of their own school positioning and talent training mode. At the same time, they are also facing the dual pressure from both the "higher vocational colleges" and "old undergraduate colleges".

Work hard to meet the needs of the development of an educationally-powerful country and focus on providing local 
applied higher education that can meet the needs of the people. In the critical period of the development of the cause of the party and the state, national development particularly needs the support of higher education. Local application-oriented colleges and universities should actively respond to the strong desire of local economic and social development for scientific knowledge and talents. With positive attitudes and more effective actions, application-oriented colleges should play their role of "local teams" in the higher education system, and strive to provide local applied higher education that can meet the needs of the people.

Work hard to meet the growing needs of the people for higher education, and focus on providing applied higher education that people can trust. The report of the 19th session of national congress of the CPC clearly pointed out that socialism with Chinese characteristics had entered a new era, and the main social contradiction of China had been the contradiction between the growing needs of the people for better life and the inadequate and unbalanced development. For local applied universities, the unbalanced social development still restricts their intension-type development in the new era. To solve this problem, the most fundamental thing is to adhere to scientific development, steadfastly implement the development concept of innovation, coordination, green, openness, and sharing, take providing localized applicationoriented higher education that people are satisfied with as the bottom line, and establish the school-running idea of basing on the local place, relying on the local place, serving the local place, integrating into the local place, highlighting local characteristics and serving local development.

\section{CONCLUSION}

Work hard to enhance the sense of gaining of teachers and students, and focus on constructing local applied universities that are supported by the people. To enhance the sense of acquisition of teachers and students, it is necessary to comprehensively construct "three degrees": First, the degree of consistency between the school's educational philosophy and the humanistic philosophy of teachers and students. Local application-oriented colleges and universities should firmly establish the school-running philosophy of "development depends on teachers and students, development is for teachers and students, and development achievements benefit teachers and students". The second is the degree of conformity between school development and teacher and student progress. Create progress channels for teachers and students, classify and formulate assessment criteria, promotion channels, and compensation systems, plan career development paths for different types of teachers, and integrate various excellent resources on professional study, social practice, campus activities, innovation and entrepreneurship to help students improve abilities. The third is the degree of support of teachers and students' creative initiative for the talent cultivation of the school. Timely discover, refine and promote the fresh experience gained by teachers and students in the practice of talent cultivation, scientific and technological innovation, social services, and cultural heritage innovation, and stimulate the enthusiasm of teachers and students to support and participate in the construction and development of the school.
The main task of newly-built application-oriented undergraduate colleges is to cultivate application-oriented senior professionals who can meet the needs of local markets, and local application-oriented undergraduate colleges are the main body for implementing local applied undergraduate education. However, due to the influence of administrative-led classification and vertical stratification of China's higher education, newly-built applied undergraduate colleges have problems such as strong administrative dependence, similar school-running models, high level of positioning, and academic talent training. Defining the application-oriented development orientation of newly-built applied undergraduate colleges will help them to develop healthily and actively, and will help to form a good situation of the coordinated development of elite higher education and mass higher education.

\section{REFERENCES}

[1] Shen Jian. Some Thoughts on Talent Cultivation in Applied Undergraduate Colleges in Jiangsu Province[J].Jiangsu Higher Education,2014(07)

[2] Wu Yana. Comparison of the training mode of applied undergraduate talents between China and Germany[J]. Continue Education Research, 2016(03) 